\title{
Tipologi Courtyard pada Permukiman Tionghoa Lasem
}

\author{
Dian Duhita \\ Jurusan Arsitektur, Fakultas Teknik Sipil dan Perencanaan, ITENAS, Bandung \\ Email:dian.duhita@gmail.com
}

\begin{abstract}
ABSTRAK
Hunian Tionghoa di Lasem Jawa Tengah merupakan salah satu peninggalan budaya di Indonesia yang masih meninggalkan warisan hingga saat ini. Hunian Tionghoa di Lasem berkembang sejak abad ke-15, dimana kawasan ini mulai membentuk kawasan pecinan khas yang dikenali melalui hunian courtyard dan gerbang masuk sebagai bagian dari fasade bangunan. Permukiman yang didirikan membentuk kawasan yang terpisah dari kawasan pribumi. Masing-masing kawasan memiliki bangunan penting berupa tempat ibadah (kelenteng) dan keraton sebagai inti permukiman. Hunian courtyard Tionghoa di Lasem memiliki unsur budaya campuran, seperti adanya elemen arsitektur bergaya Cina, kolonial serta Jawa. Tujuan penelitian ini antara lain menganalisis tipologi hunian courtyard di permukiman Tionghoa Lasem dimana terdapat akulturasi langgam arsitektur di dalamnya. Metoda penelitian yang digunakan adalah deskriptif dimana pengambilan data dilakukan secara kualitatif. Setiap tipe hunian courtyard memberikan image berbeda tergantung dari komposisi bangunan yang ada di dalamnya sehingga memiliki ciri khas tertentu. Suasana ruang courtyard dipengaruhi oleh hadirnya gerbang dengan atap ngang shan, bangunan utama berupa thienching maupun chengshen serta hulung yang melengkapi elemen hunian. Kavling hunian courtyard memiliki variasi bentuk akibat dari perubahan yang ada pada elemen fisik sehingga ruang courtyard berpotensi untuk berubah dan berkembang menjadi bangunan tumbuh.
\end{abstract}

Kata kunci: Hunian Courtyard, Permukiman Tionghoa, Lasem

\begin{abstract}
Chinese occupancy in Lasem, Central Java is one of the cultural heritages in Indonesia which still leaves a legacy until now. Chinese occupancy in Lasem developed since the 15th century, where the area began to form a distinctive Chinatown area that was recognized through courtyard and entrance gates as part of the building facade. Established settlements form a separate area from the indigenous region. Each area has an important building in the form of a place of worship (kelenteng) and a palace as the core of the settlement. Chinese courtyard occupancy in Lasem has a mixture of cultural elements, such as the presence of Chinese, colonial and Javanese architectural elements. The purpose of this study included analyzing the residential typology of courtyard in the Chinese settlement of Lasem where there was acculturation in the style of architecture. The research method used is descriptive where data collection is done qualitatively. Each type of residential courtyard gives a different image depending on the composition of the building in it so that it has certain characteristics. The atmosphere of the courtyard room is influenced by the presence of a gate with the roof of the Ngang Shan, the main building in the form of thienching and chengshen and hulung which complements the residential elements. Courtyard residential plots have a variety of forms as a result of changes in physical elements so that courtyard space has the potential to change and develop into a growing building.
\end{abstract}

Keywords: Courtyard Houses, Chinese Settlement, Lasem 


\section{PENDAHULUAN}

Hunian courtyard mencerminkan capaian budaya yang mempertimbangkan aspek iklim, budaya, aksesibilitas dan sirkulasi, simbol dan agama, aktivitas, keamanan, serta ekonomi. Fungsi ruang terbuka pada hunian courtyard memberikan sirkulasi udara dan pencahayaan alami dimana iklim yang ekstrim dapat dinetralisir di dalam area hunian courtyard. Adanya pencahayaan serta sirkulasi udara yang maksimal untuk bangunan-bangunan di dalam kavling hunian courtyard menciptakan harmoni antara alam dengan bangunan. Hunian courtyard memberikan privasi yang tinggi kepada penghuninya dimana dinding kavling dapat memisahkan kegiatan publik di luar dengan kegiatan privat di dalam. Aturan dalam penempatan fungsi bangunan di dalam kavling hunian courtyard berbeda-beda di setiap budaya. Pemisahan area untuk orang-orang yang lebih dihormati biasanya memiliki tempat yang paling nyaman dibandingkan dengan orang muda ataupun pelayan.

Lasem merupakan salah satu kecamatan di Kabupaten Rembang yang berdekatan dengan perbatasan Jawa Tengah dan Jawa Timur. Pada kecamatan ini masih ditemukan peninggalan warisan budaya berupa hunian courtyard Tionghoa yang sudah berumur ratusan tahun. Bentuk fisik hunian courtyard ini menjadi unik karena telah mengalami akulturasi dengan budaya Cina, masyarakat pribumi Jawa serta arsitektur kolonial. Kondisi kota Lasem yang awalnya cenderung mati karena mulai ditinggalkan oleh penghuninya kini beberapa bagian telah ditata kembali dimana citra kota yang berkarakter unik ini diangkat dengan menggali potensi-potensi yang ada.

\section{TINJAUAN PUSTAKA}

Hunian courtyard di setiap budaya pada kawasan bersejarah memiliki keunikan serta karakter yang berbeda-beda dimana biasanya ditandai dengan adanya nilai estetis, historis dan spiritual sehingga merupakan signifikansi budaya yang harus dilestarikan. Menurut Reynolds [1], courtyard adalah ruang khusus yang memiliki atap terbuka yang langsung berhubungan dengan luar serta dikelilingi oleh bangunan-bangunan [1]. Hunian courtyard merupakan tipologi rumah berhalaman yang sangat khas dan berkarakter yang dapat dijumpai pada beberapa budaya seperti pada rumah tradisional bangsa Cina, arsitektur Islam Timur Tengah yang memiliki sahn, Romawi kuno yang memiliki atrium, serta Itali yang memiliki patio. Menurut Das [2], hunian courtyard tidak memiliki bentuk geometri yang pasti, biasanya terdiri dari bentuk segiempat, lingkaran maupun kurva [2].

Elemen hunian courtyard terdiri dari halaman terbuka, arcade/teras dan ruangan-ruangan beratap. Area terbuka pada hunian dapat digunakan untuk segala macam aktivitas rumah tangga, seperti memasak, bekerja, bermain, bercocok tanam serta memelihara binatang peliharaan. Hunian courtyard cina diadopsi dari cina utara ke Cina selatan dengan tiga tipe dasar penggunaan dinding courtyard, yaitu seperti yang ditunjukkan pada Gambar 1 [3]:

a. Terdiri dari beberapa ruangan di sekitar courtyard, dinding belakang tiap ruangan terhubung pada dinding benteng

b. Ruangan-ruangan yang berdiri sendiri dengan membentuk courtyard dan dikelilingi dinding yang melingkupinya

c. Kombinasi dari tipe 1 dan tipe2, yaitu adanya beberapa ruangan yang masing-masing terhubung dengan dinding benteng maupun hanya dikelilingi dinding saja. 

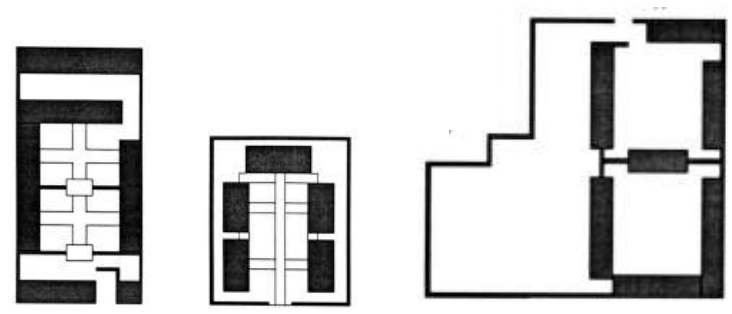

Gambar 1. Variasi letak courtyard hunian Tionghoa [3]

Hunian vernakular Indonesia juga memiliki kemiripan dengan hunian vernacular cina dimana bentuk hunian courtyard pada masyarakat Jawa Tengah menjadi ciri khasnya. Rumah Jawa adalah sebagai tempat privasi secara visual namun dapat melakukan keakraban antara anggota keluarga dimana penghuni dapat beristirahat nyaman dengan cara menarik diri dari kehidupan masyarakat di luar rumah untuk mendapatkan kebebasan [4]. Tapak dari rumah jawa seperti ditunjukkan pada Gambar 2 terdiri atas rumah utama, rumah samping dan sebuah rumah belakang [5]. Halamannya tidak berada di tengahtengah tapak namun terletak di bagian belakang dan depan dari bangunan utama. Antar bangunan di dalam hunian Jawa ini dihubungkan oleh ruang terbuka (courtyard). Hampir sama dengan hunian courtyard di Cina, ruang terbuka pada hunian Jawa difungsikan sebagai tempat bermain maupun beraktifitas para penghuni rumah tersebut.

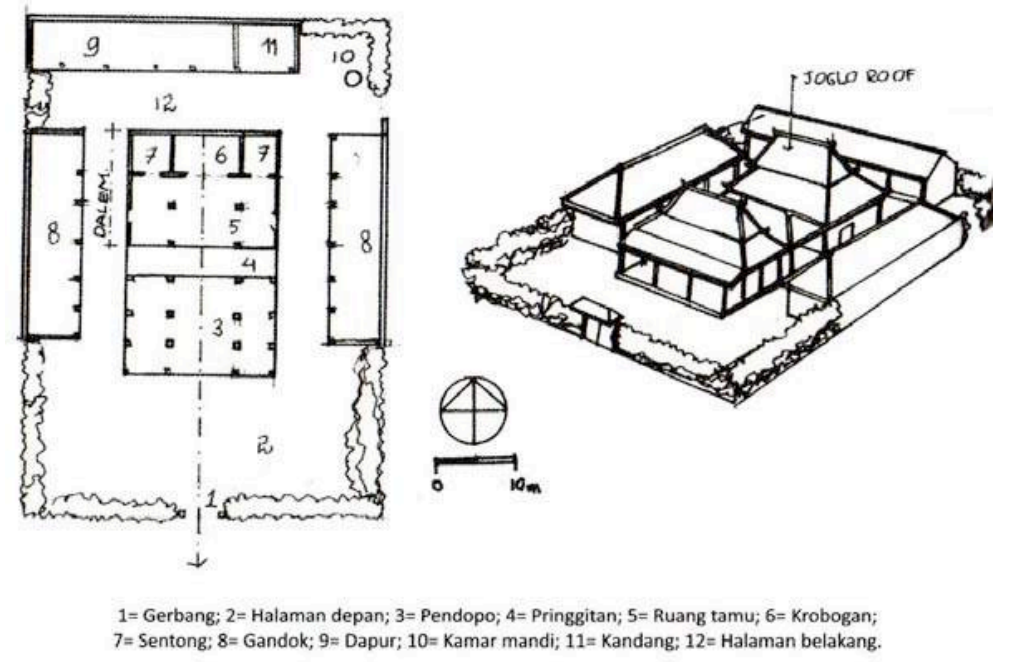

Gambar 2. Tipologi Hunian Jawa [5]

Hunian vernakular di Cina dan Jawa memiliki persamaan baik bentuk maupun nilai dimana persamaan antara keduanya jika digabungkan akan menghasilkan identitas yang memiliki nilai budaya yang sangat tinggi dengan karakter-karakter yang dapat dipertahankan, antara lain:

1. peralihan ruang di dalam hunian courtyard, yang memberikan harmonisasi bangunan dengan lingkungannya

2. hirarki yang menggambarkan penghormatan kepada leluhur dan orang yang lebih tua

3. pemisahkan ruang luar yang publik dengan ruang dalam yang privat oleh dinding hunian courtyard yang tinggi

4. tempat beristirahat, jauh dari keramaian dan hiruk pikuk di luar hunian courtyard

5. tempat memperoleh cahaya serta ventilasi udara yang cukup 


\section{METODOLOGI}

Penelitian ini mengambil studi kasus hunian warga Tionghoa di Kecamatan Lasem, Kabupaten Rembang, Propinsi Jawa Tengah. Secara khusus obyek penelitian difokuskan pada hunian courtyard warga Tionghoa yang terdiri dari beberapa karakter. Penelitian ini menggunakan pendekatan kualitatif. Metoda pengambilan data dilakukan melalui survey ke lokasi kecamatan Lasem untuk dilakukan dokumentasi. Analisis dilakukan secara deskriptif. Peta lokasi survei ditunjukkan pada Gambar 3 berikut ini.
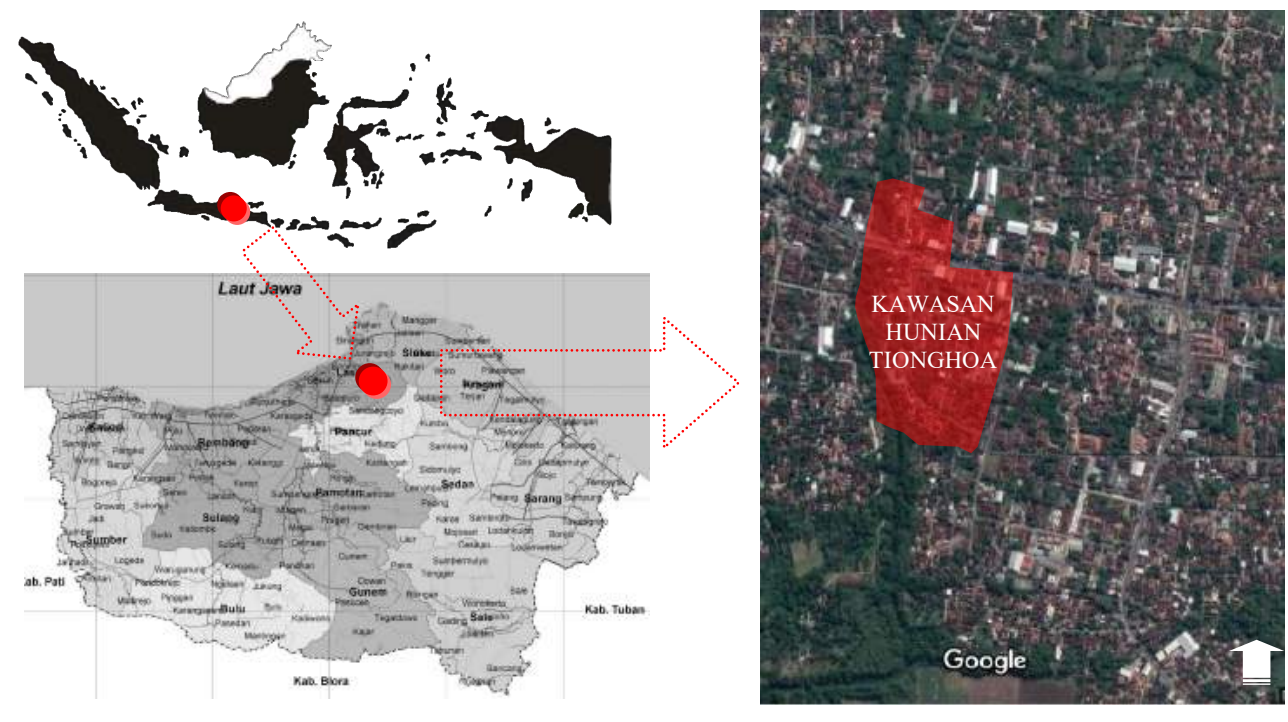

Gambar 3. Lokasi Penelitian, Kecamatan Lasem, Rembang, Jawa Tengah

\section{HASIL DAN PEMBAHASAN}

\subsection{Sejarah Perkembangan Kecamatan Lasem}

Lasem berkembang sejak abad 15 dimana warga Tionghoa mendominasi area utara yang kemudian menjadi kawasan pusat ekonomi serta warga pribumi mendominasi area selatan yang kemudian menjadi kawasan pusat pemerintahan. Pada masa ini, selain hadirnya kelenteng pelabuhan juga dibangun di sisi sungai Lasem. Pada tahun 1588 permukiman Tionghoa yang dibangun lebih teratur berada di dataran rendah sebelah timur Sungai Lasem. Sungai Lasem dimanfaatkan sebagai jalur transportasi perdagangan bagi warga Tionghoa karena tidak jauh dari permukiman tersebut didirikan pula pelabuhan dagang. Peta perkembangan pemukiman Tionghoa di Kota Lasem dapat dilihat pada Gambar 4 berikut ini. 


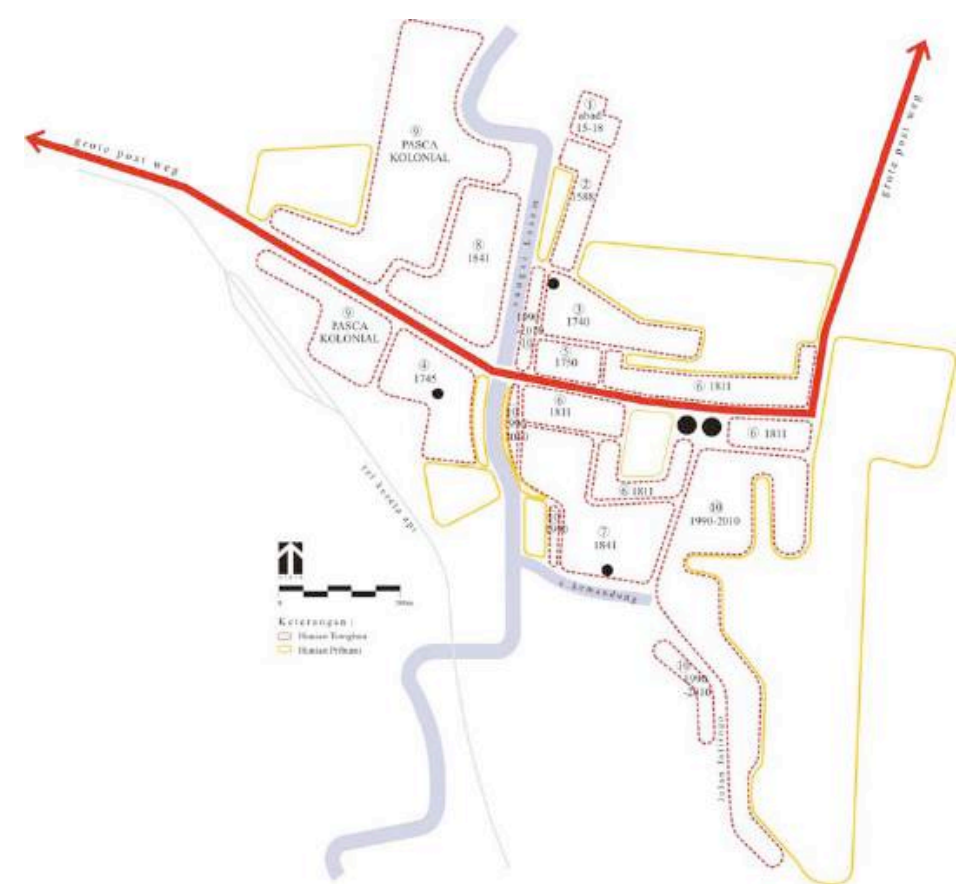

Gambar 4. Kompilasi Peta Perkembangan Permukiman Tionghoa Lasem abad 15 hingga Tahun 2019

Periode masa kolonial, perkembangan hunian Tionghoa berkembang ke arah barat daya serta mendirikan tangsi militer di maura sungai Lasem. Untuk menghindari penyelundupan yang dilakukan warga Tionghoa, Belanda merubah aliran sungai Lasem seratus meter ke arah barat hingga dok kapal tidak dapat mencapai depan hunian courtyard warga Tionghoa. Pusat pemerintahan kecamatan kemudian dipindahankan ke kota Rembang, sehingga Lasem kemudian hanya kota kecil di bawah kecamatan saja. Pada pasca kolonial, jalur sungai sudah tidak berfungsi sama sekali setelah hancurnya galangan kapal di desa Soditan. Area permukiman Tionghoa menjadi sepi karena tidak adanya kegiatan perdagangan yang signifikan. Hunian Tionghoa mulai sepi dan ditinggalkan hingga hanya warga berusia lanjut saja yang menetap di kota ini.

Dapat ditarik kesimpulan bahwa hunian Tionghoa berawal dari utara kemudian berkembang ke arah selatan dan barat yang diikuti oleh didirikannya kelenteng $\mathrm{Cu}$ An Kiong, Poo An Bio dan Gie Yong Bio serta dikelilingi oleh hunian pribumi.

\subsection{Tata Massa Bangunan Hunian Courtyard Tionghoa Lasem}

Peta figure ground kawasan menggambarkan bahwa permukiman ini didominasi oleh kavling hunian courtyard. Setiap courtyard berada di antara bangunan serta gerbang kavling. Courtyard diperlihatkan dengan warna putih sebagai void, sedangkan bangunan berada di tengah-tengahnya sebagai solid.

Intensitas bangunan di dalam kawasan cukup rendah, dimana mayoritas bangunan hunian terdiri dari satu hingga dua lantai. Sesuai Gambar 5 hunian dengan pemilik golongan menengah ke atas membentuk sebuah skyline dimana makin ke belakang bangunan semakin tinggi. Hal ini menggambarkan hirarki yang tinggi pada bangunan chengsen yang lebih privat dibandingkan dengan thienching. Sedangkan bangunan dengan penghuni golongan menengah memiliki skyline dengan bangunan thienching sebagai bangunan tertinggi karena pada bagian depan hanya terdapat gerbang serta hulung pada bagian belakang yang lebih rendah daripada bangunan utama tersebut. 


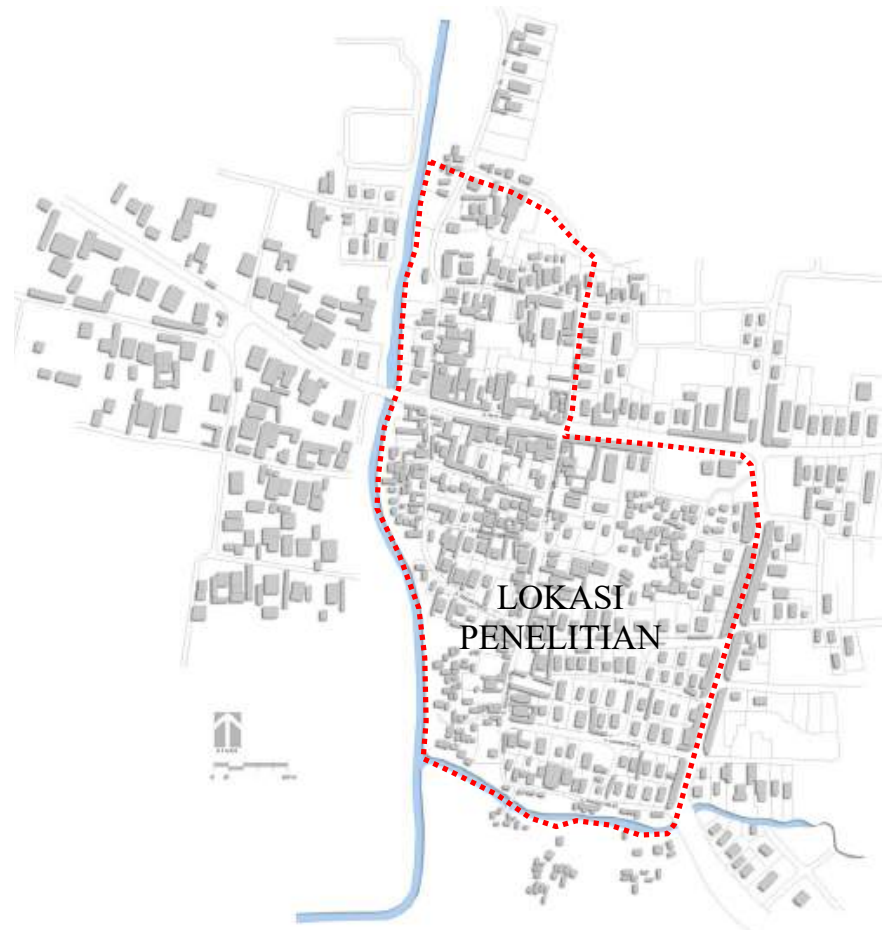

\section{Gambar 5. Peta Tata Massa Bangunan Kawasam Permukiman Tionghoa di Kecamatan Lasem}

Hunian courtyard Tionghoa Lasem terbelah oleh jalan arteri primer yang menghubungkan propinsi Jawa Tegah dengan propinsi Jawa Timur yang lebih dikenal dengan jalur pantura. Penelitian difokuskan pada hunian courtyard Tionghoa yang berada di desa Dasun dan Karangturi, dimana pada kawasan tersebut masih menyisakan banyak hunian courtyard Tionghoa dengan berbagai jenis.

\subsection{Karakter Hunian Courtyard Tionghoa Lasem}

Karakter hunian courtyard Tionghoa Lasem bila ditangkap dari area luar (koridor jalan) berupa deretan dinding putih setinggi 2 meter dengan pengulangan atap ngangshan di setiap awal kavling yang berfungsi sebagai gerbang utama. Gambar 6 menunjukkan koridor area luar hunian Courtyard di Lasem.
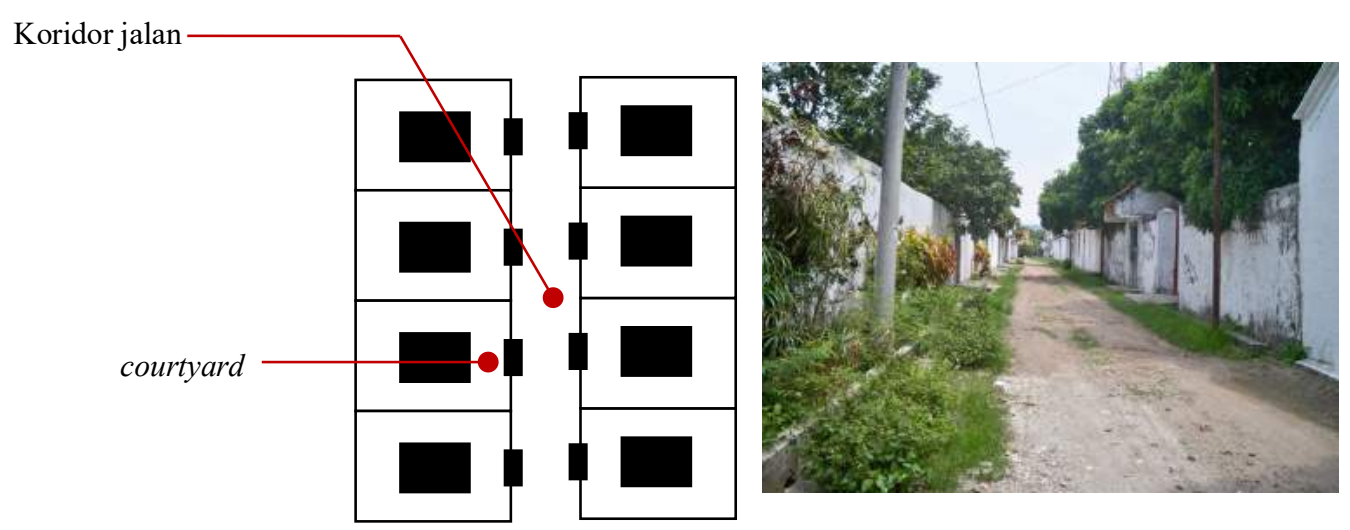

Gambar 6. Koridor area luar hunian courtyard Tionghoa Lasem

Melalui pengamatan bentuk hunian courtyard yang ada di kawasan, ditemukan 2 tipe utama dari hunian courtyard Tionghoa Lasem. Tipe pertama biasanya dimiliki oleh warga Tionghoa dengan ekonomi 
menengah atas digolongkan dalam tipe hunian courtyard massa banyak yang memiliki lebih dari bangunan utama, yaitu thienching dan chengsen. Sedangkan tipe kedua dengan courtyard yang lebih kecil digolongkan dalam tipe hunian courtyard massa tunggal dimiliki oleh mayoritas warga Tionghoa golongan menengah dengan satu bangunan utama di tengah-tengah kavling. Jenis hunian courtyard massa jamak dan tunggal ditunjukkan pada Gambar 7.

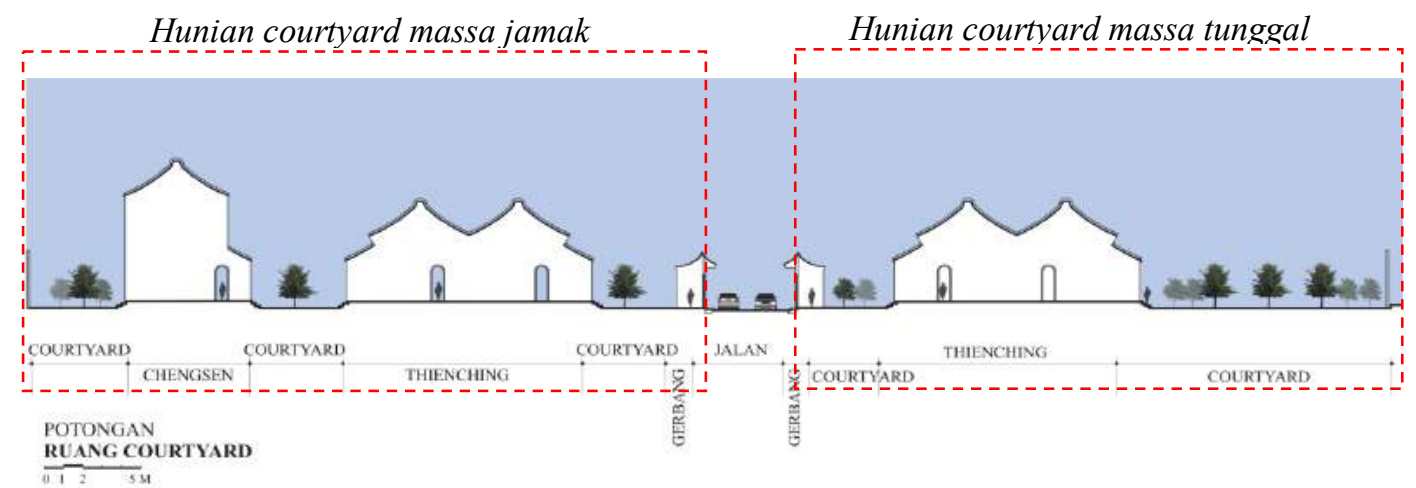

Gambar 7. Tipe utama jenis hunian courtyard Tionghoa Lasem

Bentuk umum dari hunian courtyard Tionghoa Lasem memiliki bangunan utama di tengah-tengah kavling. Namun dengan makin bertambahnya kebutuhan terhadap ruangan, maka banyak dilakukan penambahan massa bangunan baik pada samping maupun belakang bangunan utama yang pada akhirnya merubah bentuk standar dari hunian courtyard di dalam kavling tersebut. Demikian pula halnya dengan sebuah hunian courtyard yang kemudian dibagi menjadi dua akibat bertambahnya pemilik sehingga bangunan utama dari hunian courtyard yang satu saling menempel dengan bangunan utama hunian courtyard lainnya.

Material dari masing-masing bentuk hunian courtyard terdiri dari kombinasi tanah yang ditutup oleh rumput serta batu slate pada bagian terasnya. Namun pada hunian courtyard yang sudah mengalami perbaikan-perbaikan biasanya batu slate pada teras sudah diganti oleh plesteran beton maupun paving block yang lebih modern sperti yang ditunjukkan pada Gambar 8.

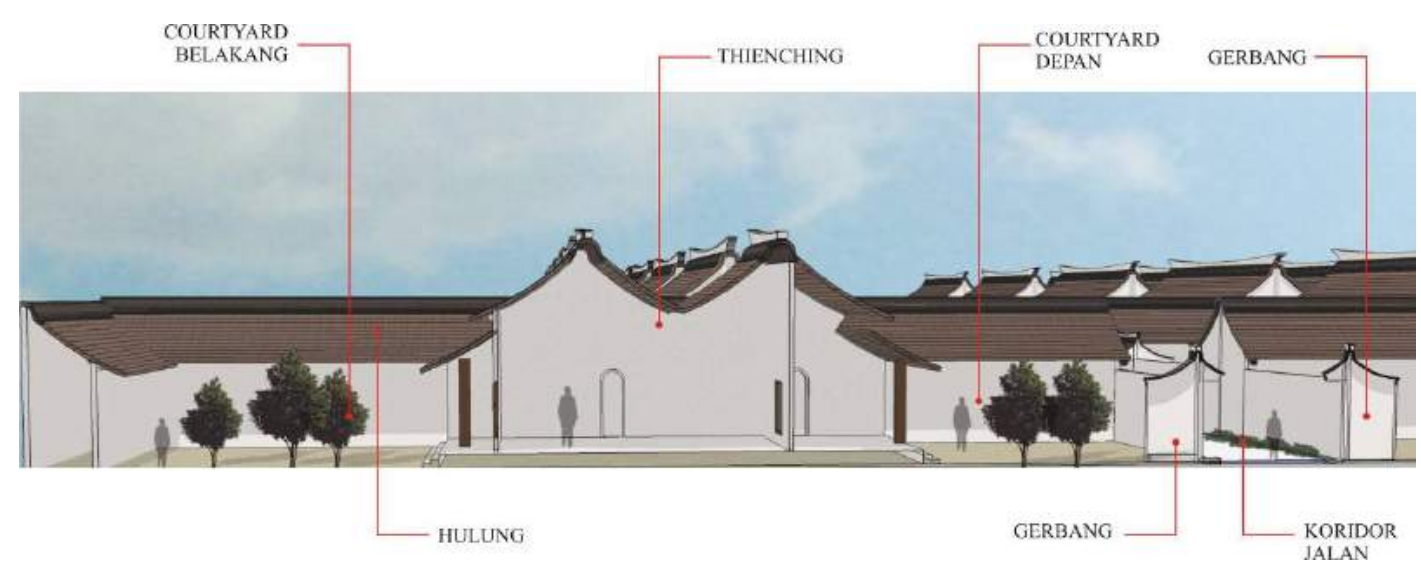

Gambar 8. Potongan Ruang courtyard Tionghoa Lasem 
Pada tipe hunian courtyard massa jamak termasuk minoritas di kota Lasem ini, salah satunya ditemukan di daerah jalan Dasun, yaitu sebelah utara jalur pantura seperti yang ditunjuukan pada Gambar 9. Hunian ini menjadi salah satu landmark di kawasan karena bentuk bangunannya yang berbeda dibandingkan dengan sekitarnya serta lahannya yang cukup luas.

Tabel 1. Tipologi Perletakkan bangunan pada Kavling Hunian Courtyard Tionghoa Lasem

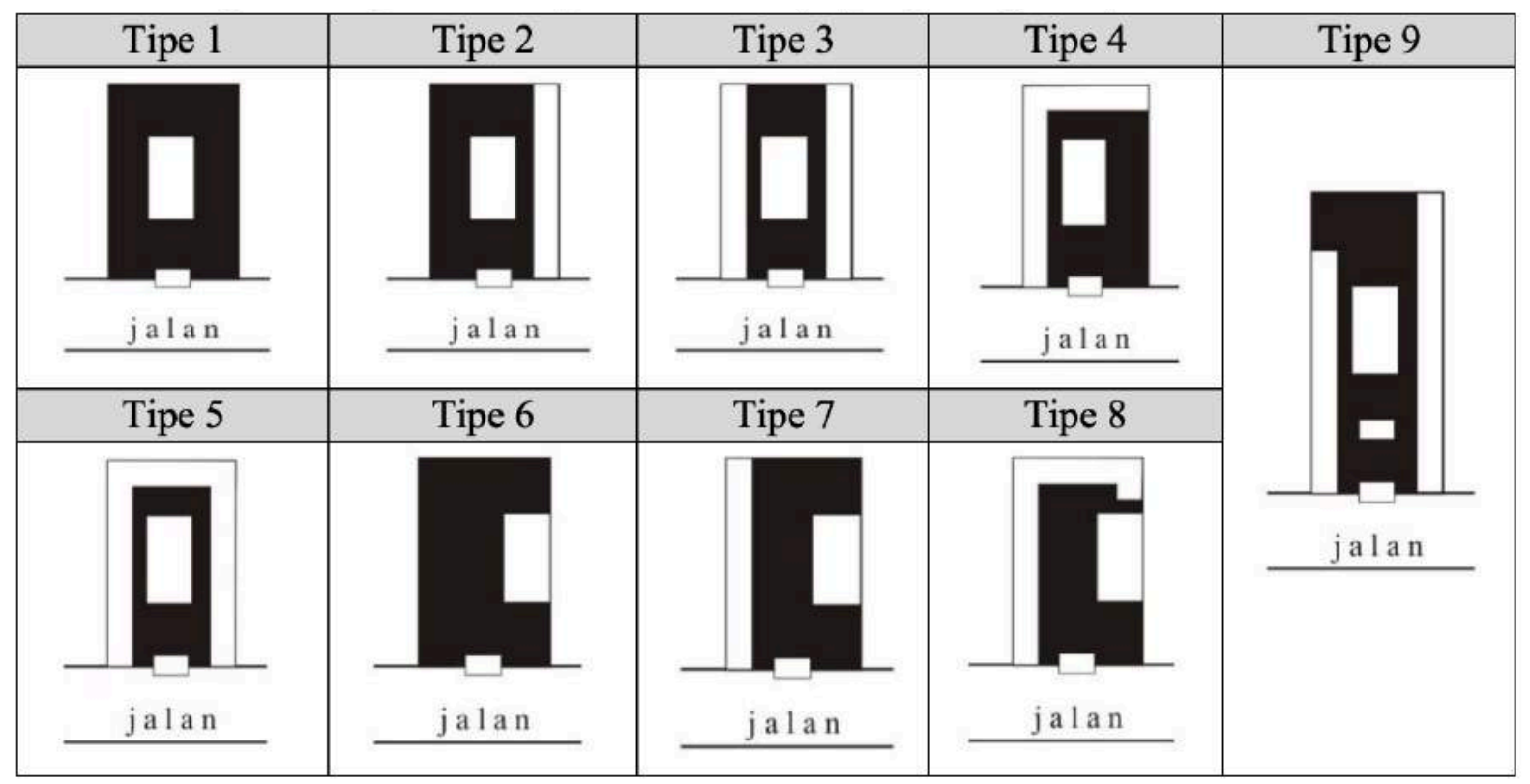

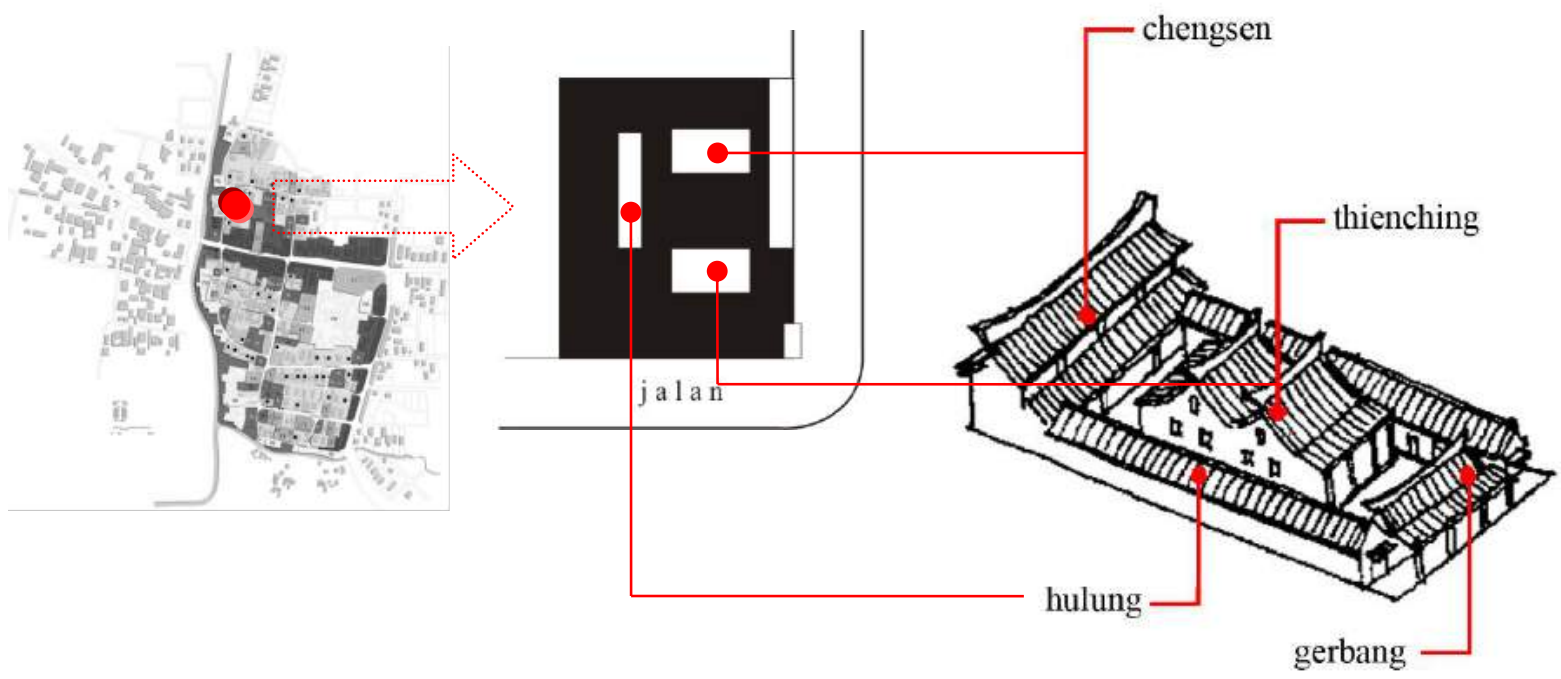

Gambar 9. Tipe hunian courtyard massa banyak [6]

Tipe hunian courtyard massa tunggal yang mayoritas lebih ditemukan di kawasan hunian ini memiliki sembilan tipe yang berbeda. Tipe ini biasanya terbentuk akibat kebutuhan terhadap ruang yang diperlukan akibat bertambahnya jumlah anggota keluarga di dalam kavling hunian courtyard tersebut. Tabel 1 menunjukkan tipe-tipe peletakan bangunan pada kavling courtyard. 


\subsection{Elemen Hunian Courtyard Tionghoa Lasem}

Elemen hunian courtyard Tionghoa dapat diklasifikasikan dalam 3 kategori yaitu gerbang, atap dan fasade bangunan. Tipe gerbang dari masing-masing hunian courtyard Tionghoa Lasem dapat dibedakan berdasarkan langgam (terdiri atas langgam Cina dan Eropa) serta material yang digunakan.

Langgam Cina pada gerbang hunian courtyard Tionghoa di kawasan ini cukup mendominasi, dimana hampir semua bangunan memiliki gerbang dengan langgam Cina baik dalam ukuran besar maupun kecil. Demikian pula halnya dengan hunian yang sudah mengalami perubahan fisik pada bangunan utama, beberapa gerbangnya tetap menggunakan langgam Cina sebagai identitas pemilik. Pada gerbang langgam Cina ini, jenisnya dapat dibedakan berdasarkan ukuran, yaitu:

a. Gerbang Kecil

Gerbang kecil seperti ditunjukkan pada Gambar 10. ini berfungsi sebagai tempat keluar masuk penghuni saja. Terdiri dari pintu kayu ukuran double beratap ngang-shan dengan dinding struktur berornamen Cina pada kedua sisinya.

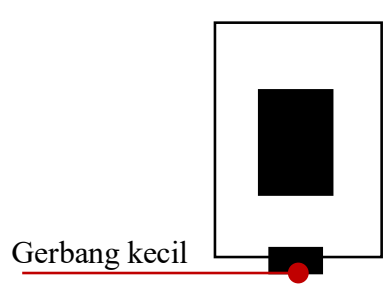

Gerbang Si He Yuan di Beijing

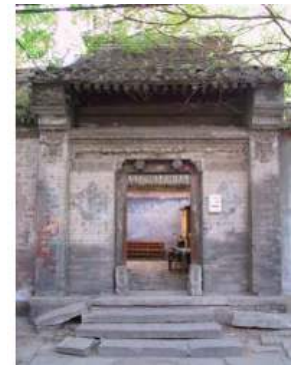

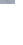

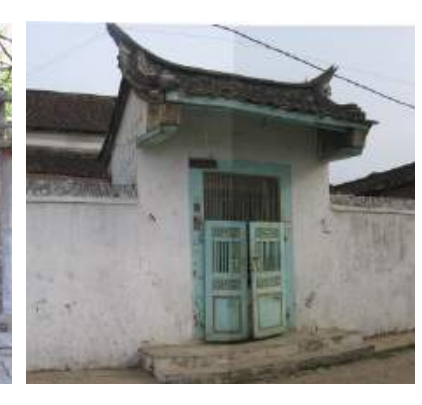

Gerbang Kecil di Lasem

\section{Gambar 10. Tipe gerbang kecil hunian courtyard [7]}

Gerbang masuk ini memiliki 2 lapis pintu, yaitu pintu kayu solid pada bagian luarnya yang biasanya terdapat tulisan dengan huruf Cina, serta pintu angin yang lebih transparan pada bagian dalamnya. Pada pagi hingga sore hari, biasanya pintu solid selalu terbuka, sehingga bangunan utama dapat terlihat melalui celah dari lubang pintu angin. Sedangkan pada malam hari pintu solid selalu dalam keadaan tertutup sehingga terkesan lebih privat dan aman jika terlihat dari luar. Gerbang kecil di Lasem ini memiliki kemiripan dengan gerbang hunian Tulou tipe Five Phoenix di Fujian Cina Selatan serta Si He Yuan di Beijing. Material dari gerbang ini adalah kombinasi dari bata pada dinding struktur utama serta kayu pada struktur atap dan pintu.

b. Gerbang Besar

Gerbang tipe ini memiliki ketinggian serta ornamen yang sama dengan gerbang kecil, namun memiliki ukuran yang panjang dan lebih lebar. Jika dilihat dari luar, gerbang ini terlihat seperti fasade bangunan utama karena ukurannya yang mirip bangunan rumah tinggal. Bagian dalam dari gerbang ini berfungsi sebagai tempat penyimpanan barang/gudang oleh penghuninya. Memiliki tipe pintu yang sama dengan gerbang kecil, yaitu pintu solid dan pintu angin. Beberapa rumah gerbang memiliki jendela di sisi kanan dan kiri dari pintu masuknya. Serupa dengan gerbang kecil, gerbang 
ini juga terdiri dari kombinasi material bata pada dindingnya serta kayu pada struktur atap dan pintu seperti ditunjukkan pada Gambar 11.
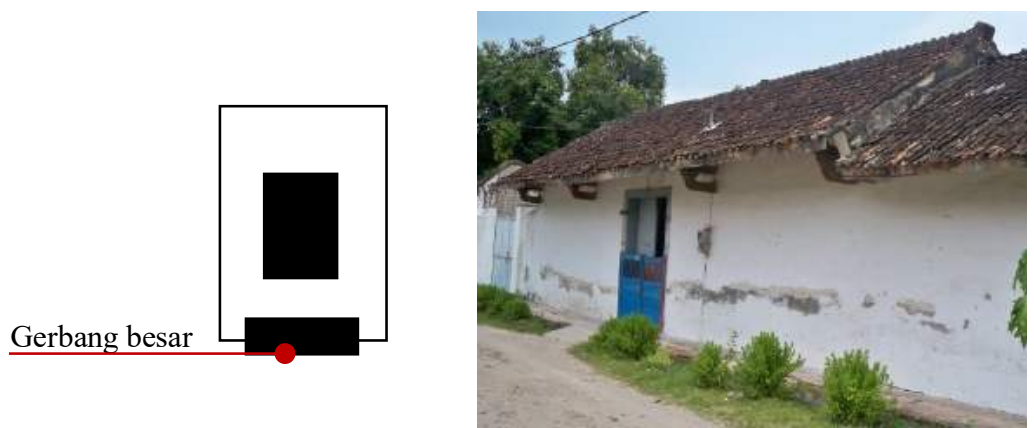

Gambar 11. Tipe gerbang besar hunian courtyard Lasem

c. Gerbang Kelenteng

Gerbang landmark seperti ditunjukkan pada Gamabr 12. hanya ditemukan pada fungsi bangunan kelenteng saja. Di Lasem tipe gerbang ini hanya ditemukan tiga buah, yaitu di kelenteng $\mathrm{Cu} \mathrm{An}$ Kiong, Poo An Bio serta Gie Yong Bio. Gerbang ini sangat monumental karena dua kali lebih tinggi dari gerbang kecil dan rumah gerbang sehingga membuat orang yang melihat langsung dapat mengenali dengan adanya landmark pada kawasan tersebut. Ornamen yang terdapat pada gerbang landmark ini biasanya berupa elemen Cina seperti tulisan, atap ngang-shan serta binatang-binatang yang dipercaya dapat memberikan keberuntungan. Material gerbang ini terdiri dari bata dan beton dimana struktur dari bawah hingga atas didominasi oleh kolom yang menjulang tinggi.
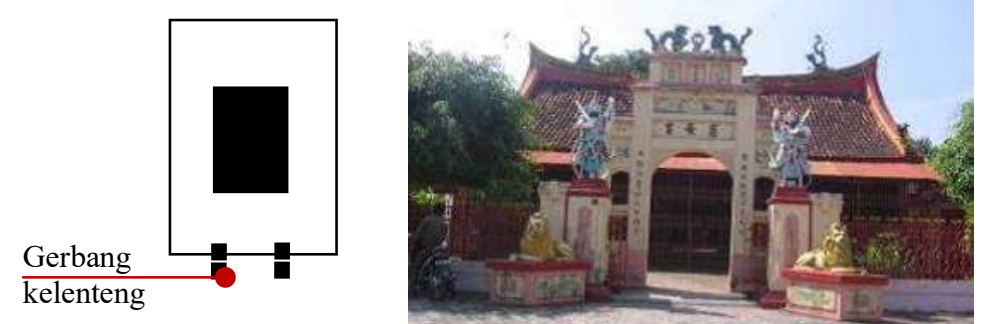

Gambar 12. Tipe gerbang kelenteng di sekitar hunian courtyard Lasem

Gerbang dengan langgam Eropa/kolonial pada awalnya merupakan gerbang Cina yang masif dan privat, namun karena adanya pencampuran budaya kolonial yang masuk ke Lasem, maka beberapa gerbang mengalami perubahan dengan bentuk yang lebih transparan tanpa adanya lagi bangunan beratap yang memisahkan area hunian courtyard dengan koridor jalan. Elemen dari gerbang Eropa ini biasanya menghadirkan pilar-pilar neoklasik serta patung burung di atas pilar tersebut. Material dari gerbang ini terdiri dari kombinasi bata dan besi. Bata biasanya digunakan sebagai pilar yang berada di sebelah kanan dan kiri gerbang sedangkan material besi digunakan pada gerbangnya. Gambar 13 menunjukkan type gerbang langgam kolonial yang berada di Lasem. 

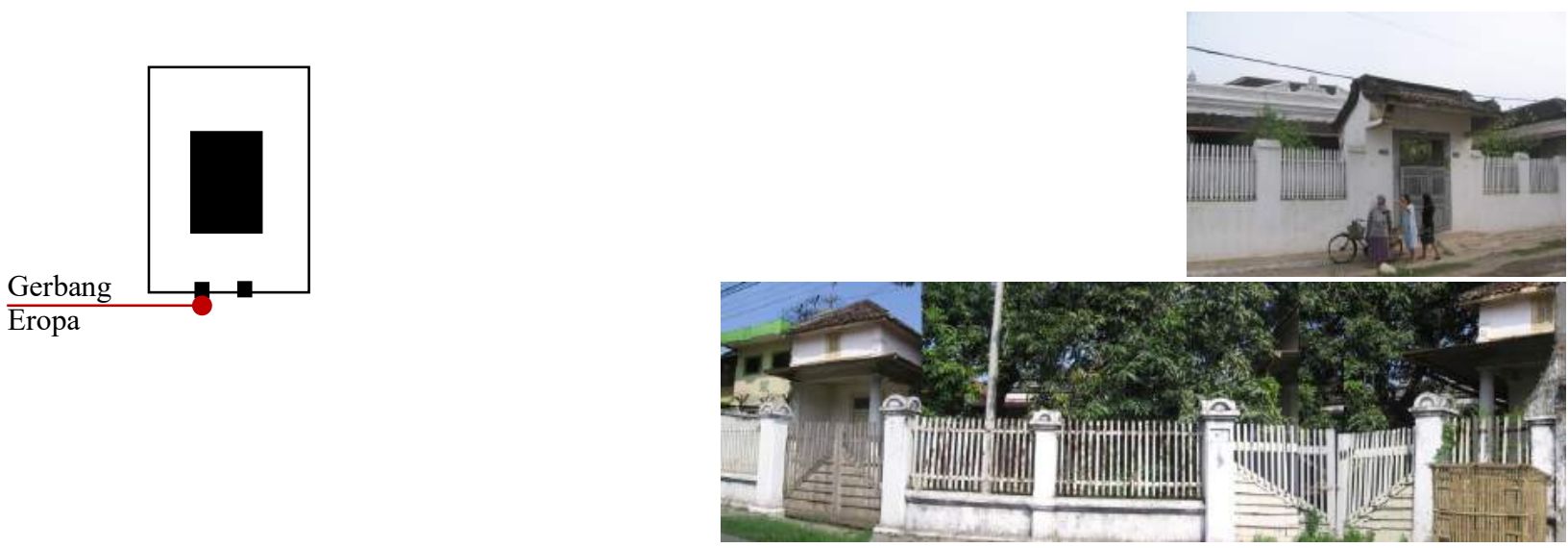

\section{Gambar 13. Tipe gerbang kolonial hunian courtyard Lasem}

Atap dari bangunan hunian courtyard Tionghoa Lasem memiliki beragam bentuk sesuai dari budaya yang mempengaruhinya. Hampir sama dengan pengaruh langgam pada bentuk gerbang, ragam bentuk atap dapat dibedakan berdasarkan langgam Cina, pribumi dan Eropa/kolonial. Atap ngang-shan seperti ditunjukkan pada gambar 14. merupakan salah bentuk atap yang banyak ditemukan di kawasan hunian ini. Tipe atap ini terdiri dari konstruksi dinding ada bagian kanan dan kiri bangunan yang menumpu struktur atap. Sedangkan struktur kayu pada kuda-kudanya digunakan struktur tou-kung yang terbuat dari material kayu. Pada bangunan utama, atap ngang-shan ini biasanya dibuat berulang, dimana pada bagian depan dari pola tata ruangnya berfungsi sebagai beranda depan, sedangkan bagian belakang atap berfungsi sebagai area altar serta beranda belakang.

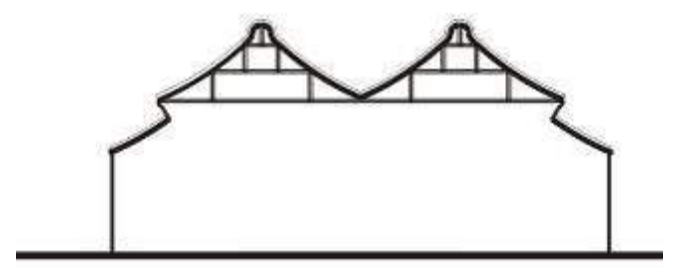

\section{Gambar 14. Atap ngang-shan Lasem}

Atap hsuan-shan ini memiliki bentuk yang mirip dengan atap dari rumah tradisional Jawa Tengah, yaitu atap serontongan. Atap ini biasa digunakan oleh warga Tionghoa Lasem, dimana pada struktur kuda-kudanya digunakan jenis tou-kung. Sketsa atap hsuan-shan ditunjukkan pada Gambar 15 berikut.
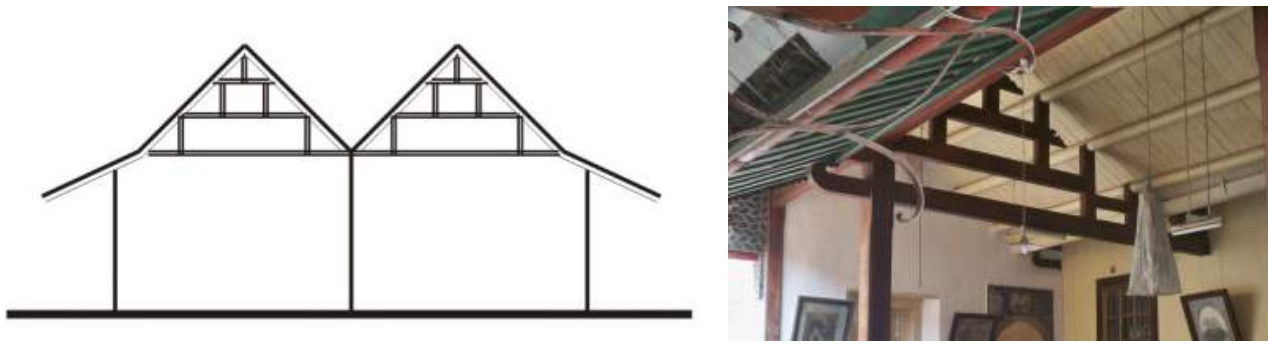

Gambar 15. Atap hsuan-shan Lasem 
Jenis atap kombinasi Ngang-shan dan Hsuan-shan seperti ditunjukkan pada Gambar 16. adalah gabungan penggunaan dua atap, yaitu atap hsuan-shan pada bangunan utamanya, sedangkan atap ngang-shan digunakan pada atap beranda bangunan utama.

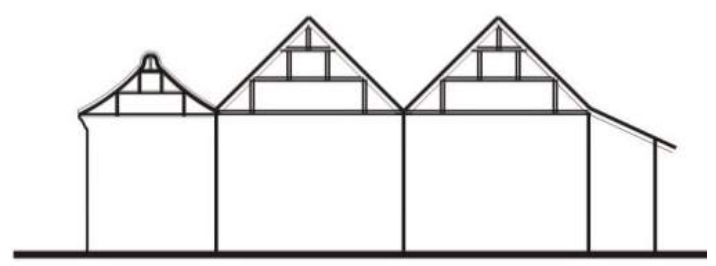

Gambar 16. Kombinasi atap ngang-shan dan hsuan-shan Lasem

Atap bangunan courtyard yang terpengaruh oleh langgam Pribumi dikenal dengan atap serontongan. Atap serontongan yang merupakan tradisional dari rumah Jawa Tengah biasanya banyak digunakan oleh warga pribumi kota Lasem pada umumnya, namun tidak sedikit pula warga Tionghoa yang menggunakannya. Atap ini tidak menggunakan konstruksi toukung seperti pada atap hsuan-shan namun hanya menggunakan konstruksi atap yang sederhana. Sketsa atap serotongan dapat dilihat pada Gambar 17. Meskipun menggunakan jenis atap ini, warga Tionghoa biasanya tetap menggunakan jenis atap ngang-shan pada gerbang courtyard-nya.
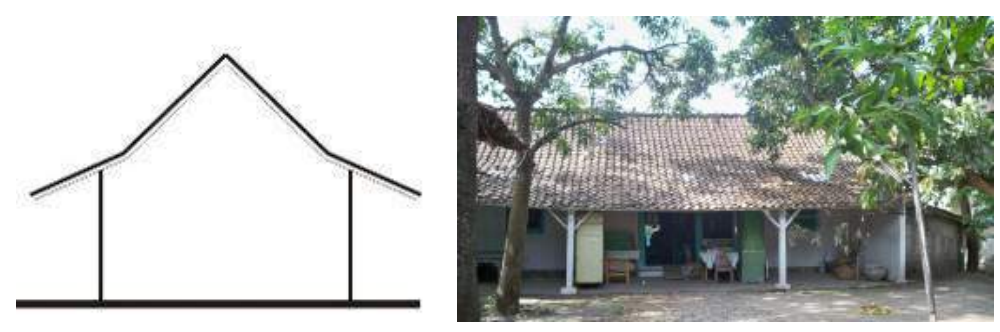

\section{Gambar 17. Atap serontongan di hunian courtyard Tionghoa Lasem}

Atap perisai ini mulai hadir di kota Lasem ketika kolonial Belanda mulai menguasai kota ini. Meskipun Belanda tidak mendirikan bangunan hunian untuk dirinya sendiri di Lasem namun tidak sedikit hunian Tionghoanya merubah fasade langgam Cina menjadi langgam Eropa. Perubahan tersebut berpengaruh pada perubahan atap ngang-shan maupun hsuan-shan menjadi jenis atap perisai yang menggunakan konstruksi kayu kuda-kuda $\mathrm{V}$ Truss dengan ornamen neoklasik di bagian depan atapnya seperti ditunjukkan pada Gambar 18.
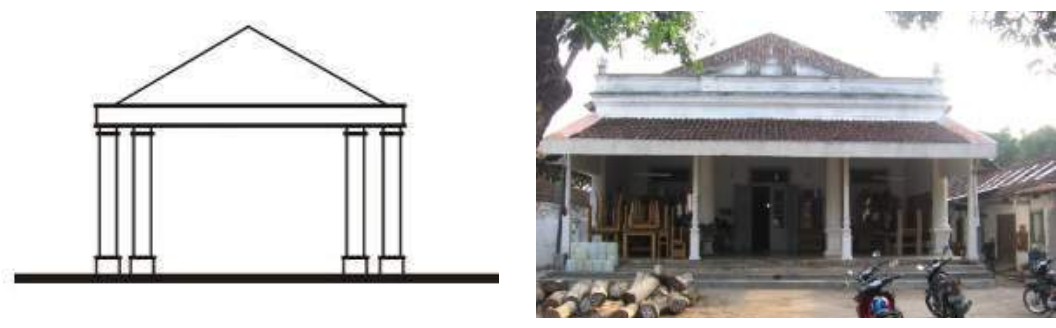

Gambar 18. Atap kolonial di hunian courtyard Tionghoa Lasem 
Fasade dari tiap hunian courtyard Tionghoa Lasem memiliki kemiripan satu sama lain yaitu hanya berupa dinding putih tinggi yang monoton serta gerbang Cina setiap beberapa meter sebagai tanda area masuk huniannya. Namun pada bangunan utama (thienching) dari hunian tersebut terdapat beberapa perbedaan, yaitu bentuk asli yang diadaptasi serta akulturasi dari budaya barat. Hunian asli Cina ini memiliki kemiripan dengan hunian di Shanxi, Cina Utara. Fasadenya cenderung masif dimana kedua jendela yang berada di sisi kanan dan kiri pintu hanya setinggi dua pertiga dari dinding. Pintu dari bangunan ini dilengkapi dengan beberapa tulisan Cina yang dipercaya dapat mengundang keberuntungan. Ornamen lainnya yang didapati berupa konstruksi kuda-kuda, mahkota pada dinding penahan atap serta balustrade pada podium teras depan seperti ditunjukkan pada Gambar 19.
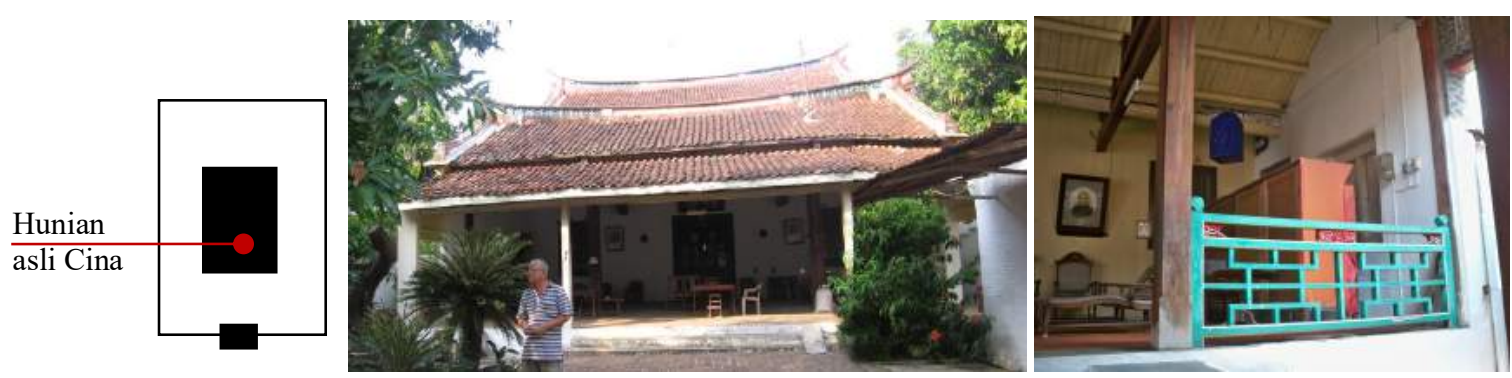

Gambar 19. Fasade dan ornament hunian asli Cina di hunian courtyard Tionghoa Lasem

Fasade hunian hasil akulturasi dengan kolonial Belanda menghasilkan bentuk yang lebih transparan. Bukaan pada jendela yang berada di sisi kanan dan kiri pintu dibuat lebih tinggi dibandingkan dengan rumah asli Cina. Teritisan atapnya lebih pendek sehingga perlu dilengkapi kanopi tambahan yang berfungsi melindungi beranda dari air hujan serta sinar matahari. Fascia board atau lisplank diletakkan di pinggiran kanopi sedangkan kolom-kolom dilengkapi dengan capital di bagian atas serta pedestal di bagian bawah. Sketsa Fasade dapat dilihat pada Gambar 20.

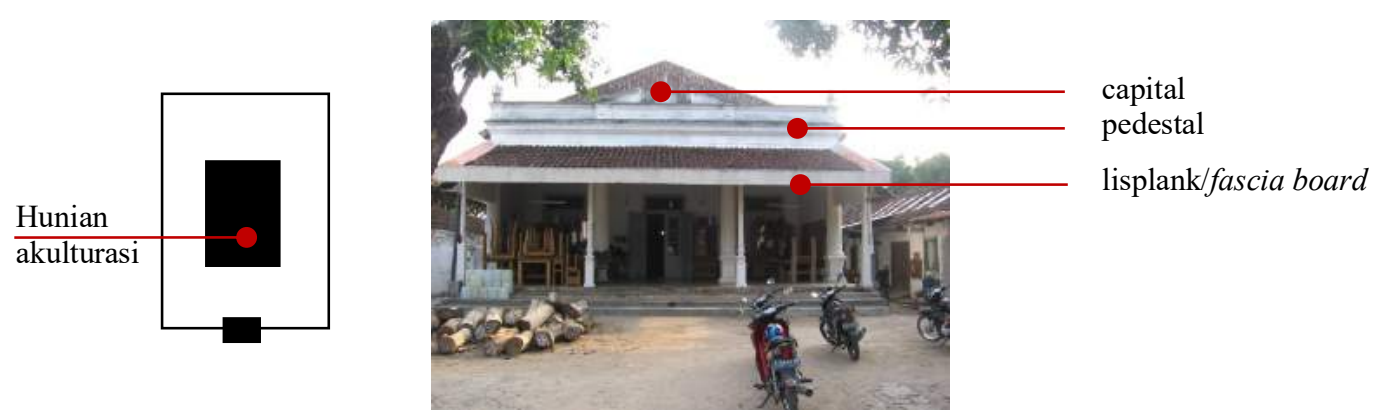

Gambar 20. Fasade akulturasi kolonial hunian courtyard Tionghoa Lasem

\section{SIMPULAN}

Hunian courtyard Lasem terbentuk menjadi karakter lingkungan hunian courtyard yang berupa koridor panjang dan menerus akibat deretan dinding pagar dari kavling serta area dalam hunian courtyard. Area dalam hunian courtyard ini memiliki dua tipe utama dimana masing-masing dibedakan berdasarkan jumlah massa bangunan yang ada di dalam kavling yang mengelilingi courtyard tersebut. Setiap tipe hunian courtyard memberikan image berbeda tergantung dari komposisi bangunan yang ada di 
dalamnya. Meskipun memiliki kemiripan ekspresi antara hunian courtyard satu dan lainnya namun masing-masing hunian courtyard tetap memiliki ciri khas tertentu. Suasana ruang dipengaruhi pula oleh hadirnya gerbang dengan atap ngang shan, bangunan utama berupa thienching maupun chengshen serta hulung yang melengkapi elemen hunian courtyard. Budaya pribumi dan eropa/kolonial juga mempengaruhi elemen arsitektur hunian courtyard.

Berdasarkan bentuk massa bangunan yang telah mengalami penambahan ruangan pada hulung, memungkinkan bahwa kavling hunian courtyard berpotensi untuk berubah dengan membelah bangunan utama menjadi dua bagian sama besar sehingga menghasilkan bentuk hunian courtyard baru yang dapat dianalogikan sebagai sebuah hunian courtyard yang dicerminkan (tipe 6, tipe 7 dan tipe 8 pada tabel Tipologi Perletakkan bangunan pada kavling Hunian Courtyard Tionghoa Lasem). Variasi pada bentuk hunian courtyard juga terjadi akibat perubahan yang ada pada elemen fisik, dimana setiap bangunan berpotensi untuk berubah dan berkembang menjadi bangunan tumbuh.

\section{DAFTAR PUSTAKA}

[1] Reynolds, John. (2002). Courtyards: Aesthetic, Social and Thermal Delight. New York: John Wiley.

[2] Das, Nibedita. (2006). Courtyards Houses of Kolkata: Bioclimatic, Typological and Socio-Cultural Study. Manhattan: Master of Architecture, Kansas State University.

[3] Hu, Zhihong, B.Arch. (1998). The Interpretations of Chinese Walls: Architecture as Matchmaker. Texas: Master of Architecture, Texas Tech University.

[4] Santosa, Revianto Budi. (2000). Omah Membaca Makna Rumah Jawa. Yogyakarta: Yayasan Bentang Budaya.

[5] Pratiwo. (2010). Arsitektur Tradisional Tionghoa dan Perkembangan Kota. Yogyakarta: Penerbit Ombak.

[6] Sunartio, Anindhita N. (2001). Perancangan Kawasan Pusat Kota Lama Lasem, Studi Kasus: Lingkungan Sekitar Alun-Alun Lasem. Bandung: Magister Arsitektur, ITB.

[7] Tibet Heritage Fund International. (2002). Beijing Hutong Conservation Plan. Beijing: THF. 